Supporting Information for

\title{
Anthraquinone-Mediated Fuel Cell Anode with an Off-Electrode Heterogeneous Catalyst Accessing High Power Density when Paired with a Mediated Cathode
}

Yuliya Preger, ${ }^{\mathrm{a}}$ Mathew R. Johnson, ${ }^{\mathrm{b}}$ Sourav Biswas, ${ }^{\mathrm{b}}$ Colin W. Anson, ${ }^{\mathrm{b}}$ Thatcher W. Root, ${ }^{\mathrm{a} *}$ and Shannon S. Stahl ${ }^{\mathrm{b} *}$

${ }^{a}$ Department of Chemical and Biological Engineering, University of Wisconsin-Madison 1415 Engineering Drive, Madison, Wisconsin, 53706

${ }^{\mathrm{b}}$ Department of Chemistry, University of Wisconsin-Madison, 1101 University Avenue, Madison, Wisconsin, 53706

\section{Table of Contents:}

twroot@wisc.edu; stahl@chem.wisc.edu

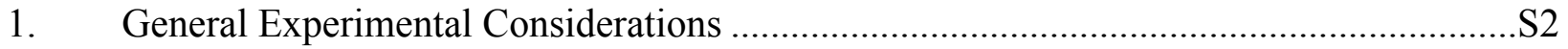

2. Batch hydrogenation of anthraquinone-2,7-disulfonic acid .......................................S3

3. Characterization of hydrogenated anthraquinone-2,7-disulfonic acid .............................S5

4. Assembly and operation of mediated fuel cell ............................................................S7

5. Transfer dehydrogenation of formic acid and $\mathrm{MeOH}$ with AQDS................................S11

6. Power density calculations for previously reported mediated fuel cells.......................S12

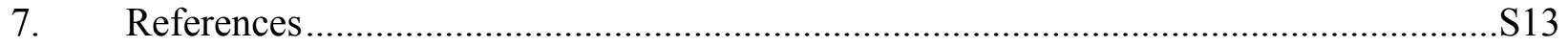




\section{General Experimental Considerations}

All commercially available compounds and solvents were purchased and used as received, unless otherwise noted. The anthraquinone-2,7-disulfonic acid, disodium salt (AQDS-Na $\left.a_{2}\right)$ was purchased from TCI Chemicals.

To increase solubility for $1 \mathrm{M}$ scale experiments, the anthraquinone was flushed through a column containing Amberlyst $15 \mathrm{H}$ ion-exchange resin to remove the sodium ions. According to inductively coupled plasma-optical emission spectroscopy (ICP-OES), $<1 \%$ of the sodium ions remained after this treatment.

The 10 wt.\% commercial Pt/C catalyst used throughout the manuscript was purchased from Strem Chemicals (78-1610).

Nuclear magnetic resonance studies. ${ }^{1} \mathrm{H}$ NMR spectra were recorded on a Bruker Avance III 400 or 600 $\mathrm{MHz}$ spectrometer. Chemical shift values are given in parts per million relative to $\mathrm{H}_{2} \mathrm{O}\left(4.79 \mathrm{ppm}\right.$ for $\left.{ }^{1} \mathrm{H}\right)$ or pivalic acid in $\mathrm{D}_{2} \mathrm{O}{ }^{1}$

Precautions were taken to exclude air from hydrogenated anthraquinone samples during analysis. Samples of hydrogenated anthraquinone were injected through septa caps into $\mathrm{N}_{2}$-purged NMR tubes. Preparation of samples for NMR exclusively used nitrogen-purged deuterated solvents and internal standards. Furthermore, $\mathrm{N}_{2}$-purged vials were used during UV-visible analysis, unless otherwise noted.

Cyclic voltammetry studies. Cyclic voltammetry (CV) measurements were performed using a BASi potentiostat and cell stand. A glassy carbon working electrode was polished with alumina before each experiment. $\mathrm{A} \mathrm{Ag} / \mathrm{AgCl}$ reference electrode and $\mathrm{Pt}$ wire counter-electrode were also used. The $\mathrm{Ag} / \mathrm{AgCl}$ was calibrated with ferroin in $1 \mathrm{M} \mathrm{H}_{2} \mathrm{SO}_{4}(1.06 \mathrm{~V}$ vs. NHE). All measured potentials are reported relative to NHE.

UV-visible studies of anthraquinone species. Reaction conditions employed for the UV-visible spectroscopic studies of anthraquinone speciation are provided in the figure caption associated with each experiment. UV-visible spectra were measured on an Agilent Cary 60 instrument using a $1 \mathrm{~cm}$ path length cuvette, except during spectroelectrochemical experiments. 


\section{Batch hydrogenation of anthraquinone-2,7-disulfonic acid}

For the time course shown in Figure 3, a solution of $0.25 \mathrm{M}$ anthraquinone-2,7-disulfonic acid, disodium salt in $1 \mathrm{M}$ sulfuric acid $(7 \mathrm{~mL})$ was added to a glass reaction vessel with $0.5 \mathrm{~mol} \%$ of the $\mathrm{Pt} / \mathrm{C}$ catalyst (Figure S1). The mixture was stirred until all of the catalyst was well-dispersed in the solution. The glass vessel was covered with a Teflon cap with four port holes. For potentiometric monitoring of the reaction, a glassy carbon working electrode and $\mathrm{ag} / \mathrm{AgCl}$ reference electrode were inserted through the port holes into the reaction solution. The progress of the reaction was monitored by connecting the electrodes to a voltmeter and recording the potential change over time. Hydrogen was bubbled into the solution through a needle in the third port hole and the fourth port hole served as a vent.

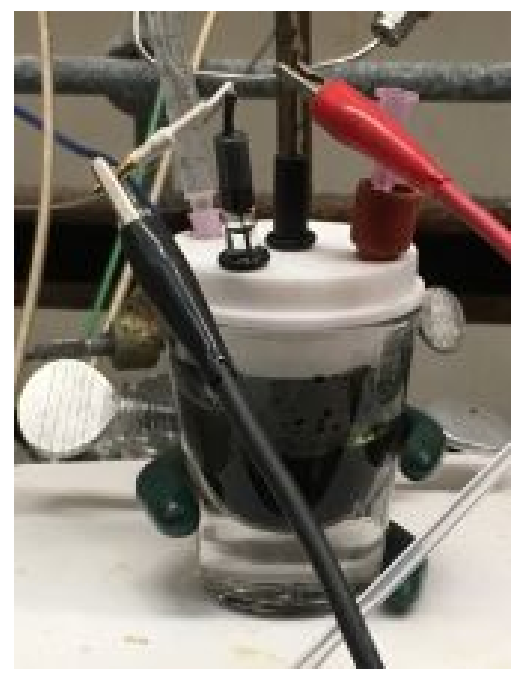

Figure S1. Batch hydrogenation of anthraquinone-2,7-disulfonic acid, disodium salt with reaction monitoring by potentiometry.

The measured potential was converted to the relative amount of oxidized and reduced species using the Nernst equation (Eq. S1). $E_{1 / 2}$ is the half-wave potential of the mediator and $n$ is the number of electrons transferred in the reaction.

$$
\mathrm{E}=E_{1 / 2}+\frac{0.059}{n} \log _{10} \frac{[Q]}{\left[\mathrm{H}_{2} Q\right]}
$$

To calibrate the electrodes, mixtures of anthraquinone:anthrahydroquinone in 75:25, 50:50, and 25:75 ratios were prepared. The anthraquinone was used as purchased and dissolved in $1 \mathrm{M} \mathrm{H}_{2} \mathrm{SO}_{4}$. To generate the anthrahydroquinone, anthraquinone was hydrogenated over a $\mathrm{Pt} / \mathrm{C}$ catalyst in $1 \mathrm{M} \mathrm{H}_{2} \mathrm{SO}_{4}$. The pure anthraquinone and anthrahydroquinone solutions were mixed in the appropriate ratios at $0.25 \mathrm{M}$ total concentration and their potentials were measured.

Figure S2 shows a sample calibration curve based on the average of three measurements generated using this approach. The $E_{1 / 2}$ from the calibration at $0.25 \mathrm{M}\left(0.219 \mathrm{~V}\right.$ vs. NHE) was consistent with the $E_{1 / 2}$ from cyclic voltammetry at $10 \mathrm{mM}\left(E_{1 / 2}=0.220 \mathrm{~V}\right.$ vs. NHE). The $\sim 60 \mathrm{mV}$ slope was consistent with a $1 \mathrm{e}^{-}$ process. Previous $\mathrm{CV}$ analyses at $1 \mathrm{mM}$ were consistent with a $2 \mathrm{e}^{-}$process. $^{2}$ The higher-than-reported slope is attributed to dimerization of the species, as previously suggested by Brushett and coworkers. ${ }^{3}$ At low concentrations $(0.1 \mathrm{mM})$, a clear isosbestic point is observed during the hydrogenation of AQDS (see Figure S3). However, an intense green color is observed when the hydrogenation is conducted at a concentration 
of $0.25 \mathrm{M}$ (see Figure S1), which may be attributed to the formation of a quinhydrone complex (1:1 complex between oxidized and reduced forms).

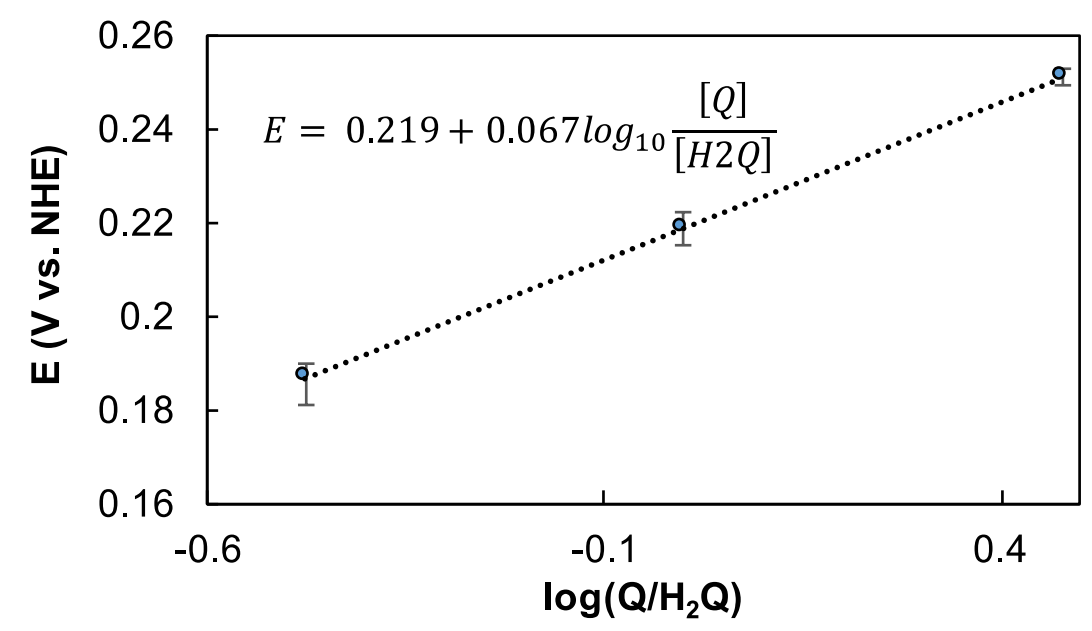

Figure S2. Calibration curve for anthraquinone-2,7-disulfonic acid relating solution potential to relative amounts of quinone and hydroquinone species. 


\section{Characterization of hydrogenated anthraquinone-2,7-disulfonic acid}

Spectroelectrochemistry was used to generate a UV-Visible spectroscopy-based assay for the detection of anthrahydroquinone-2,7-disulfonic acid. A solution containing $0.1 \mathrm{mM}$ anthraquinone-2,7-disulfonic acid, disodium salt and $1 \mathrm{M} \mathrm{H}_{2} \mathrm{SO}_{4}$ was added to a cuvette with a $1 \mathrm{~mm}$ path length. A constant potential was applied at a Pt grid electrode immersed in the cuvette, along with a Pt wire counter electrode and an $\mathrm{Ag} / \mathrm{AgCl}$ reference electrode. Potentials up to $200 \mathrm{mV}$ above and below the $E_{1 / 2}$ were applied to generate various compositions of the quinone and hydroquinone (Figure S3). After a new potential was applied, the current was allowed to equilibrate before recording a UV-Vis spectrum. The spectrum obtained when a potential of $400 \mathrm{mV}$ vs. NHE is applied shows a single peak at $328 \mathrm{~nm}$, corresponding to the anthraquinone. In contrast, the spectrum obtained when a potential near $0 \mathrm{mV}$ vs. NHE is applied shows a peak at $389 \mathrm{~nm}$, which correlates to the anthrahydroquinone. By applying different potentials, various ratios of anthraquinone and anthrahydroquinone can be generated, and the spectra exhibits an isosbestic point at 353

$\mathrm{nm}$, suggesting that at this concentration the only two species in solution are the anthraquinone and the anthrahydroquinone.

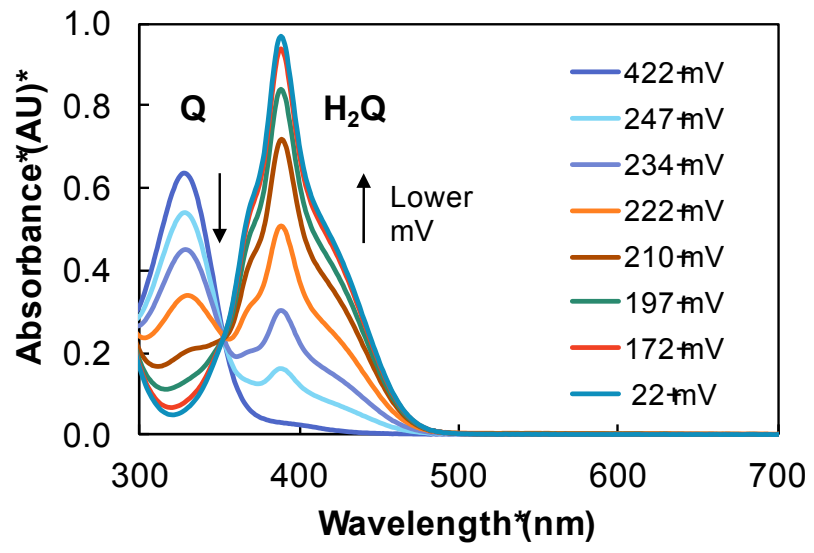

Figure S3. Spectroelectrochemistry of anthraquinone-2,7-disulfonic acid, disodium salt $(0.1 \mathrm{mM})$ in $1 \mathrm{M} \mathrm{H}_{2} \mathrm{SO}_{4}$ on a Pt grid electrode. Potentials of 22 to $422 \mathrm{mV}$ vs. NHE were applied.

The UV-visible spectrum resulting from the hydrogenation of AQDS- $\mathrm{Na}_{2}$ over a $\mathrm{Pt} / \mathrm{C}$ catalyst shows peaks consistent with the quinone and hydroquinone from spectroelectrochemistry (Figure S4). Given the high absorbance values, the spectrum should be used for confirmation of the presence of both species rather than precise determination of relative concentrations.

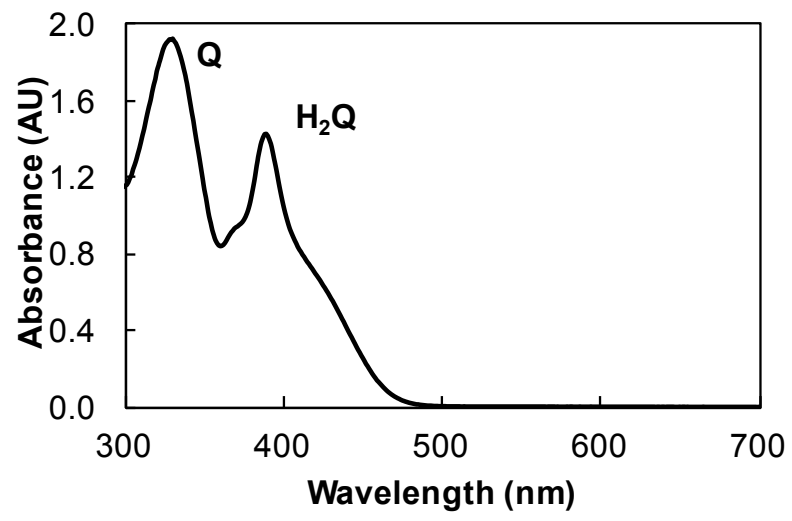


Figure S4. Spectrum of anthraquinone-2,7-disulfonic acid, disodium salt in $1 \mathrm{M} \mathrm{H}_{2} \mathrm{SO}_{4}$ following hydrogenation over a Pt/C catalyst.

${ }^{1} \mathrm{H}$ NMR spectroscopic characterization was used to confirm the reversible formation of anthrahydroquinone under reaction conditions. Samples were taken to characterize the mediator solution before and after prolonged use as a mediator under operating fuel cell conditions, and the known autoxidation process was then used to confirm re-formation of the initial species (Figure S5).

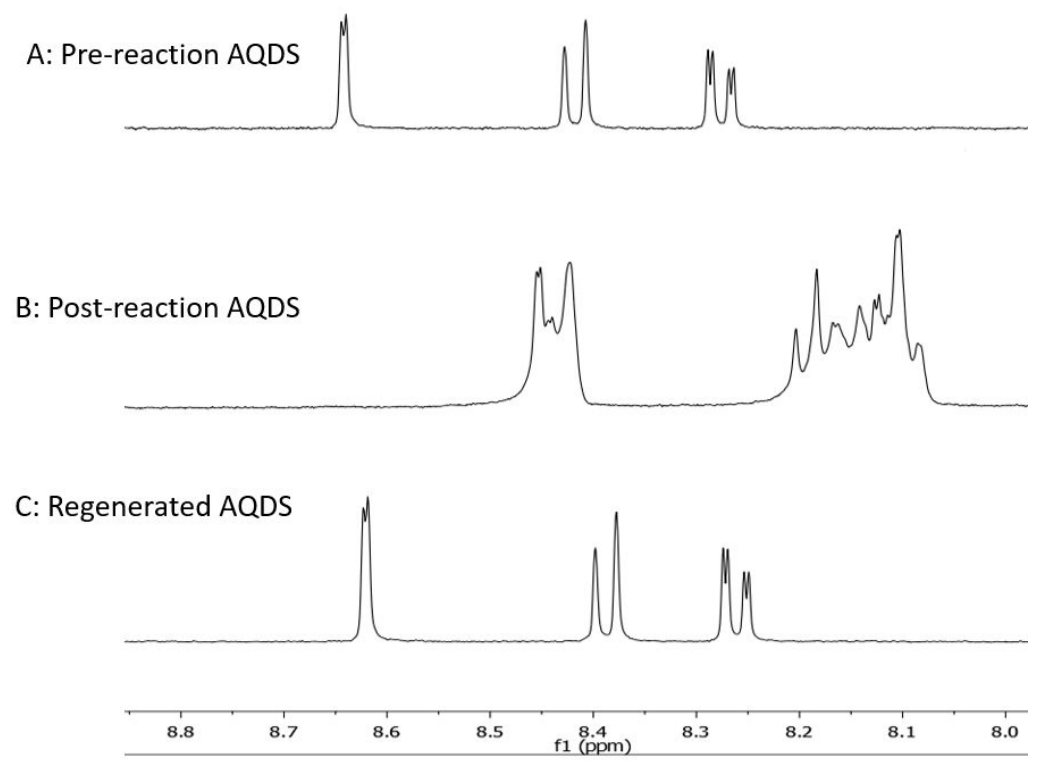

Figure S5. A) Ion-exchanged sample of AQDS: ${ }^{1} \mathrm{H}$ NMR (400 MHz, $\left.\mathrm{D}_{2} \mathrm{O}\right): 8.62(\mathrm{~d}, J=1.8 \mathrm{~Hz}, 2.0 \mathrm{H}), 8.39 \mathrm{ppm}$. (d, $J=8.1 \mathrm{~Hz}, 2.0 \mathrm{H}), 8.26(\mathrm{dd}, J=8.1 \mathrm{~Hz}, 1.9 \mathrm{~Hz}, 2.0 \mathrm{H}) \mathrm{ppm}$. B) Ion-exchanged AQDS after use as an anodic mediator for more than 8 hours (see Figure 5b). The complex multiplets are the result of overlap between oxidized and reduced AQDS. C) Sample B after exposure to air. The reduction is fully reversible, and no side peaks are observed. The slight peak shift between Panels A and C is attributed to a minor difference in concentration between the two samples, ${ }^{3}$ which were obtained as separate aliquots and diluted from $1.0 \mathrm{M}$ to $\sim 0.1 \mathrm{M}$ of quinone/hydroquinone mixture. The residual solvent peak was used as a reference for chemical shifts. 


\section{Assembly and operation of mediated fuel cell}

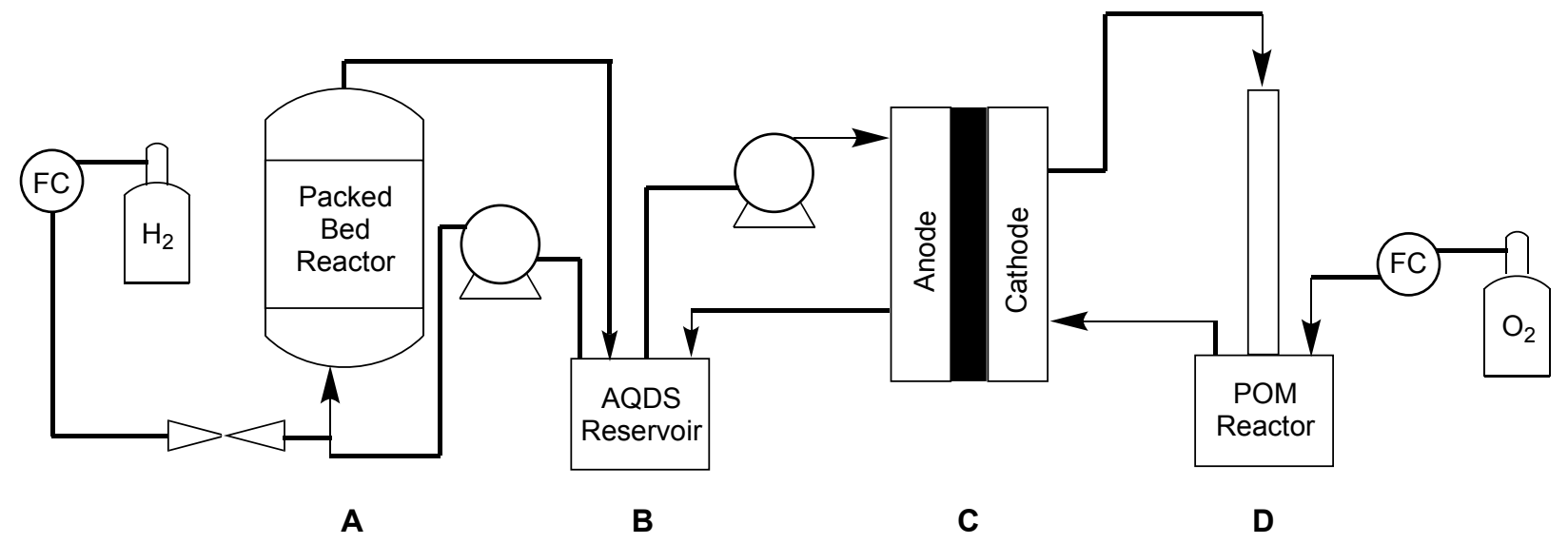

A.

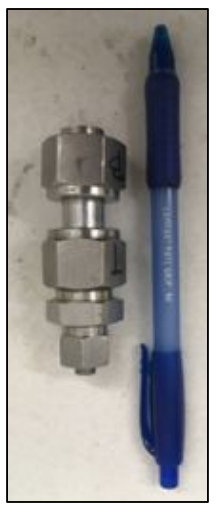

B.

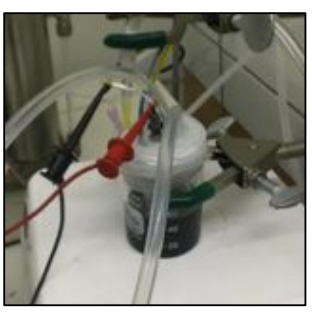

C.

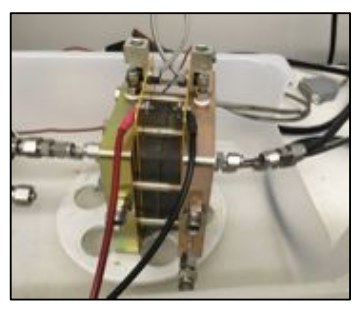

D.

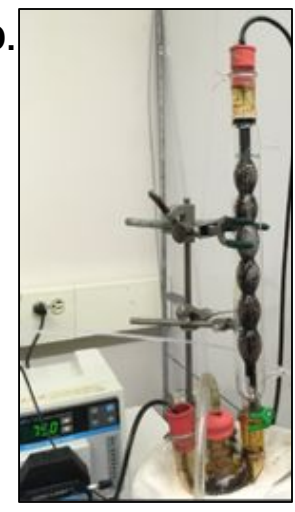

Figure S6. Schematic of fuel cell integrated with oxidation and reduction reactors (top; FC $=$ fuel cell test station) and photographs of various components of the mediated fuel cell. A) Packed bed hydrogenation reactor. B) Reservoir between hydrogenation reactor and fuel cell. C) Fuel cell. D) POM oxidation reactor.

\section{Fuel Cell}

The fuel cell hardware was supplied by Fuel Cell Technologies and the fuel cell test station by Scribner Associates Inc. The membrane electrode assembly (MEA) used a Nafion115 membrane sandwiched between $5 \mathrm{~cm}^{2}$ carbon cloth electrodes (Avcarb 1071HCB). This was enclosed by two PTFE gaskets, graphite blocks with serpentine flow channels, current collectors (gold-plated copper plates), and aluminum heating blocks.

Fluid was circulated through the fuel cell using Cole-Palmer peristaltic pumps and Masterflex Tygon ELFL tubing. The tubing was selected to minimize $\mathrm{O}_{2}$ permeability. $1 / 8$ in. PTFE tubing passing through the heating blocks to the flow plates prevented fluid/metal contact. 


\section{Anode-Side Preparation}

A glass beaker (reservoir, Figure $\mathrm{S} 6 \mathrm{~B}$ ), with $80 \mathrm{~mL}$ of ion-exchanged $1 \mathrm{M}$ AQDS solution in $1 \mathrm{M} \mathrm{H}_{2} \mathrm{SO}_{4}$ was placed between the fuel cell and the reactor to enable operation at different flow rates $(50-100 \mathrm{~mL} / \mathrm{min}$ for the fuel cell to minimize mass transfer losses and up to $6 \mathrm{~mL} / \mathrm{min}$ for the reactor to minimize pressure drop through the powder catalyst bed). This reservoir was sparged with $\mathrm{N}_{2}$ to ensure that no $\mathrm{H}_{2}$ was included in the solution flowed through the anode compartment. A pump circulated the contents of the reservoir through a packed bed reactor. After reacting over the catalyst, the electrolyte was returned to the reservoir. To monitor the extent of the anthraquinone reduction, a working electrode (glassy carbon) and a reference electrode $(\mathrm{Ag} / \mathrm{AgCl})$ were placed in the reservoir. The solution color changed from orange/brown to green as the anthraquinone was reduced. At higher states of charge, or SoC (more anthrahydroquinone), the green color faded to yellow-orange, suggesting the break-up of the hydroxyanthraquinone-anthraquinone dimer.

The packed-bed reactor was made from a 1.75 inch length of 0.5 inch OD stainless steel tube with 0.5 inches of glass wool inside a Swagelok fitting with a 200-mesh stainless steel screen. Powdered catalyst ( $0.25 \mathrm{~g}$ of commercial $10 \mathrm{wt}$ \% $\% \mathrm{Pt} / \mathrm{C}$ from Strem Chemicals) was added, leaving 0.75 inches of open space for more glass wool to be retained by another 200-mesh stainless steel screen and Swagelok fitting.

The liquid solution was pumped through the reactor using a Hitachi L-6200 HPLC pump. The flow rate of $\mathrm{H}_{2}$ was controlled by a Teledyne Hastings mass flow meter. The gas and liquid were mixed in an $1 / 8$ in. tee and sent through a heated zone, after which they passed through the packed-bed reactor in an up-flow configuration. The pre-heated zone and packed bed reactor were wrapped in heating tape and the temperature maintained at $50{ }^{\circ} \mathrm{C}$ based on a built-in thermocouple touching the reactor wall.

\section{Cathode-Side Preparation}

A $0.3 \mathrm{M}$ solution of the polyoxometalate (POM) $\mathrm{Na}_{4} \mathrm{H}_{3} \mathrm{PMo}_{8} \mathrm{~V}_{4} \mathrm{O}_{40}$ was synthesized according to the procedure disclosed in Odyakov et al. ${ }^{4}$

During fuel cell experiments, the solution was stored in a three-neck flask heated to $80{ }^{\circ} \mathrm{C}$ in a heating mantle. Solution was circulated to the fuel cell cathode from one neck (through a septum) and returned to the flask through a column of glass beads at another neck (to spread the solution and facilitate gas-liquid contact). An oxygen sparger was inserted at the third neck through a septum. The oxygen exited through the column of glass beads, in counter-current flow to the descending liquid solution. To facilitate reoxidation of the POM, care was taken to ensure that oxygen exited the flask only through the column. The solution color changed from blue/green to red/yellow as the POM was oxidized.

A liquid mediated cathode based on a polyoxometalate was used in the previous experiments because early experiments with a gas diffusion cathode had shown evidence of cathode flooding (Figure S7). A polarization curve completed with $30 \mathrm{~mL} / \mathrm{min}$ of $0.1 \mathrm{M}$ AQDS- $\mathrm{Na}_{2}$ in $1 \mathrm{M} \mathrm{H}_{2} \mathrm{SO}_{4}$ at the anode (approximately $50 \%$ state-of-charge) and $0.2 \mathrm{~L} / \mathrm{min}_{2}$ at the cathode led to a power density of $43 \mathrm{~mW} / \mathrm{cm}^{2}$. Replacement of the gaseous cathode with a $75 \mathrm{~mL}$ reservoir of $0.3 \mathrm{M} \mathrm{Na}_{4} \mathrm{H}_{3} \mathrm{PMo}_{8} \mathrm{~V}_{4} \mathrm{O}_{40}$ flowing at 50 $\mathrm{mL} / \mathrm{min}$ increased the power density to $177 \mathrm{~mW} / \mathrm{cm}^{2}$. With the gaseous cathode, the MEA consisted of a 5 $\mathrm{cm}^{2}$ Nafion 117 membrane with a $0.2 \mathrm{mg} \mathrm{Pt} / \mathrm{cm}^{2}$ cathode and a piece of carbon cloth (Avcarb 1071HCB) for the anode. With the liquid cathode, the MEA included a $5 \mathrm{~cm}^{2}$ Nafion 115 membrane with a piece of Avcarb 1071HCB carbon cloth at both the anode and cathode. The gaseous cathode experiment was the only instance in which a Nafion 117 membrane was used. Given that water crossover was a reduced concern with a liquid cathode, a slightly thinner membrane (Nafion 115) was used in all subsequent experiments to minimize membrane resistance and improve device performance. 


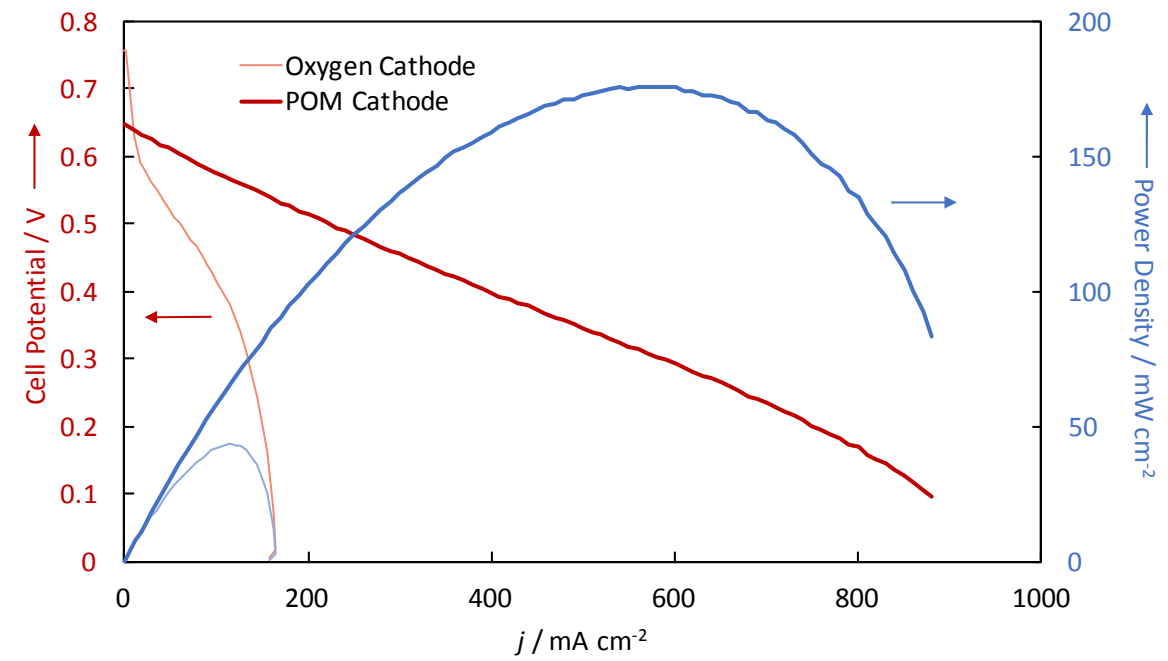

Figure S7. Polarization and power density curves with a standard $\mathrm{O}_{2}$ cathode (i.e., a gas diffusion electrode) and with a liquid POM-mediated cathode.

\section{Considerations for Fuel Cell Experiments}

Previous work by Aziz and coworkers (cf. ref. 27) has examined the influence of AQDS SOC from 10-90\% on the cell potential of a redox flow battery (which is conceptually related to the work here). At high SOCs $(>\sim 75 \%$ ), changes to the SOC have little impact on the the cell performance. In the present work, polarization curves were carried out with an SOC of $85 \%$, which allows for assessment of optimal peformance metrics. The constant current experiments were carried out at intermediate SOCs $(55 \%$ and $70 \%$ ) because the fuel cell performance is more sensitive to the SOC in this intermediate regime and, thus, allows for better assessment of the reactor peformance.

\section{Conditions for Polarization Curve Experiments}

Freshly-made POM solution in the oxidized form was used as-prepared. The anthraquinone solution in the reservoir was circulated through the packed bed reactor at a flow rate of $6 \mathrm{~mL} / \mathrm{min}$ with $30 \mathrm{~mL} / \mathrm{min}$ of $\mathrm{H}_{2}$ until the reservoir state of charge was over $85 \%$. Then the flow of both the anolyte $(70 \mathrm{~mL} / \mathrm{min})$ and catholyte $(120 \mathrm{~mL} / \mathrm{min})$ through the fuel cell was initiated and polarization curves were collected. iRcompensated data was based on the default fuel cell high frequency resistance measurement.

\section{Conditions for Constant Current Experiments}

In this experiment, $120 \mathrm{~mL}$ of freshly-made POM solution in its oxidized form was used. The flow rate of the anthraquinone solution through the packed bed was $4 \mathrm{~mL} / \mathrm{min}$ and the $\mathrm{H}_{2}$ flow rate was $20 \mathrm{~mL} / \mathrm{min}$. The anolyte and catholyte were both flowed through the fuel cell at $40 \mathrm{~mL} / \mathrm{min}$ using a peristaltic pump. PharMed tubing was used in the peristaltic pump head to minimize wear over the extended duration. The fuel cell test station applied a current of $50 \mathrm{~mA} / \mathrm{cm}^{2}$ and the anode mediator state of charge held at $70 \%$. A relatively constant potential of $560 \mathrm{mV}$ vs. RHE was maintained for a period of eight hours. The results are depicted in Figure 5b.

In a separate experiment, the hydrogen flow to the anode regenerator was turned off and on to show that the current was sustained by continuous regeneration of the mediator in the reactor, rather than an excess of pre-reduced mediator (Figure S8). A current density of $50 \mathrm{~mA} / \mathrm{cm}^{2}$ (total current of $0.25 \mathrm{~A}$ ) was set, and the anode mediator state of charge was approximately 55\%. For the first hour of operation, $\mathrm{O}_{2}$ and $\mathrm{H}_{2}$ flowed through their respective regenerators and a steady voltage was maintained. After approximately one hour, the flow of hydrogen was stopped, preventing any further AQDS reduction, though the solution continued to be pumped through the regenerator. The fuel cell was still capable of drawing current, due to 
previously reduced quinone mediator in the reservoir. As expected, the observed voltage began to drop, corresponding to a decrease in the AQDS- $\mathrm{H}_{2}$ concentration (from approximately 55\% state of charge to $42 \%)$. Once $\mathrm{H}_{2}$ flow was restarted after 139 minutes from the beginning of the experiment $\left(\mathrm{H}_{2}\right.$ off for approximately 80 minutes), further reduction of the anthraquinone was possible, and the cell potential stabilized.

Note: A stabilization of cell potential (rather than an increase) is the expected result for this experiment. The cell potential is higher when the fraction of reduced mediator is higher. For the amount of reduced mediator to change at any point during the experiment, there must be an imbalance in the rate of mediator oxidation at the anode (determined by the set current density) and the rate of mediator reduction in the reactor (set by the kinetics and experimental conditions such as $\mathrm{H}_{2}$ flow rate). When the reactor is turned back on, the rate of mediator oxidation at the anode and the rate of mediator reduction in the reactor are still approximately balanced (as they were at the start of the experiment). Thus, the relative amount of reduced mediator and the cell potential should not change.

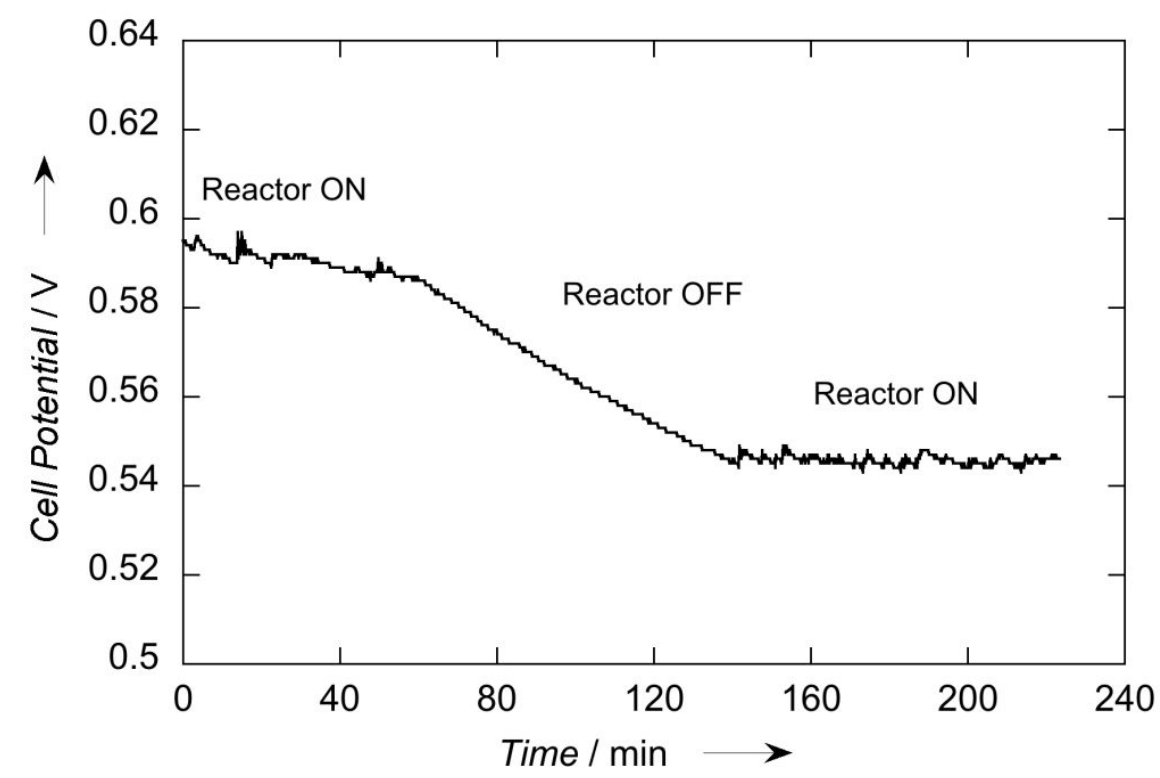

Figure S8. Operation of fuel cell integrated with mediator regenerator. Constant current experiment at $50 \mathrm{~mA} / \mathrm{cm}^{2}$ with $1 \mathrm{M} \mathrm{AQDS}$ in $1 \mathrm{M} \mathrm{H}_{2} \mathrm{SO}_{4}$ at the anode and $0.3 \mathrm{M} \mathrm{POM}$ at the cathode. $\mathrm{H}_{2}$ flow to the regenerator turned off at 55 minutes and back on at 139 minutes.

A ${ }^{1} \mathrm{H}$ NMR spectrum of a reservoir aliquot taken at the conclusion of integrated reactor-fuel cell experiments did not show any degradation peaks (see Figure S5c). 


\section{Transfer dehydrogenation of formic acid and $\mathrm{MeOH}$ with AQDS}

Formic acid: $0.4 \mathrm{M}$ AQDS-Na $\mathrm{N}_{2}$ was dissolved in water with $2 \mathrm{M}$ formic acid. The solution $(1.5 \mathrm{~mL})$ was placed in a Parr pressure reactor with $1.5 \mathrm{~mol} \% \mathrm{Pt} / \mathrm{C}$. The reactor was purged with $\mathrm{N}_{2}$ five times and heated to $50{ }^{\circ} \mathrm{C}$. After $3 \mathrm{~h}$ of reaction, the heat was turned off and the reactor was allowed to cool to $<40{ }^{\circ} \mathrm{C}$. Upon cooling, the solution was run through a glass wool-celite plug to remove the catalyst. The filtrate was diluted to $<1 \mathrm{mM}$ with $1 \mathrm{M} \mathrm{H}_{2} \mathrm{SO}_{4}$ for $\mathrm{UV}$-visible spectroscopy. Filtration and dilution were carried out quickly to minimize autoxidation of any formed hydroquinone, however, no substantial effort was taken to keep the sample air-free. Following reaction, the anthraquinone solution appeared green and the UV-Vis spectrum confirmed the presence of anthrahydroquinone (Figure S9).

MeOH: 0.2 M AQDS- $\mathrm{Na}_{2}$ was dissolved in $1 \mathrm{M} \mathrm{H}_{2} \mathrm{SO}_{4}$ with $2 \mathrm{M} \mathrm{MeOH}$. The solution $(1.5 \mathrm{~mL})$ was placed in a Parr pressure reactor with $2.5 \mathrm{~mol} \% \mathrm{Pt} / \mathrm{C}$. The reactor was purged with $\mathrm{N}_{2}$ five times and heated to 85 ${ }^{\circ} \mathrm{C}$. After reaction, the heat was turned off and the reactor was allowed to cool to $<40{ }^{\circ} \mathrm{C}$. Upon cooling, the solution was run through a glass wool-celite plug to remove the catalyst. The filtrate was diluted to $<1$ $\mathrm{mM}$ with $1 \mathrm{M} \mathrm{H}_{2} \mathrm{SO}_{4}$ for UV-visible spectroscopy. Filtration and dilution were carried out quickly to minimize autoxidation of any formed hydroquinone, however, no substantial effort was taken to keep the sample air-free. Following reaction, the anthraquinone solution appeared green and the spectrum confirmed the presence of anthrahydroquinone (Figure S9).

In both cases, the ratios of the hydroquinone and quinone peaks are not indicative of the full extent of reaction given that some of the anthrahydroquinone was autoxidized during the work-up. More rigorous analysis of non- $\mathrm{H}_{2}$ mediated fuel cell chemistries is the focus of ongoing work.

A.

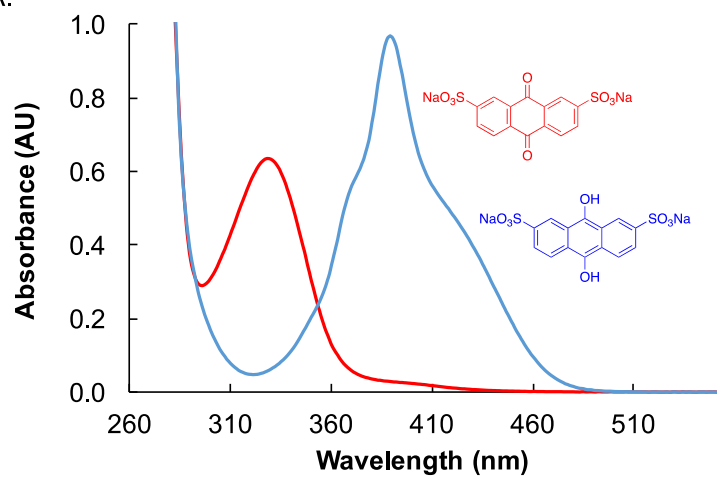

B.

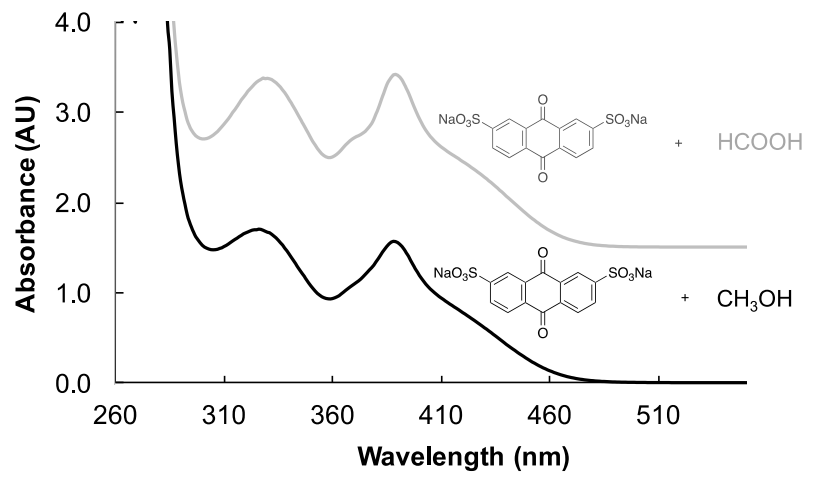

Figure S9. A) Pure anthraquinone and anthrahydroquinone peaks of AQDS-Na 2 , taken from Figure S3. B) Spectrum of anthraquinone-2,7-disulfonic acid, sodium salt in $1 \mathrm{M} \mathrm{H}_{2} \mathrm{SO}_{4}$ following reaction with formic acid and with $\mathrm{MeOH}$. Note: The spectrum for formic acid was shifted up by $1.5 \mathrm{AU}$ from the experimental value to facilitate comparison. 


\section{Power density calculations for previously reported mediated fuel cells}

Table S1. Summary of fuel cells using anodic mediators with $\mathrm{H}_{2}$ as the fuel.

\begin{tabular}{|c|c|c|c|}
\hline Redox Couple & Reference & Experimental Conditions & 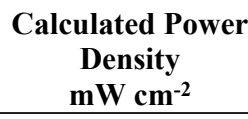 \\
\hline $\mathrm{Ti}^{3+} / \mathrm{TiO}^{2+}$ & 5 & $\begin{array}{l}\mathrm{Ti} \text { anode mediator }(0.1 \mathrm{~V} \text { vs. NHE) hydrogenated over Pd black; } \\
\mathrm{Br}_{2} / 2 \mathrm{Br} \text { cathode mediator }\left(1.065 \mathrm{~V} \text { vs. NHE) oxidized by } \mathrm{NO}_{\mathrm{x}} \text {. }\right. \\
0.95 \mathrm{~V} \text { OCV. } 7 \text { cells in series, each } 2 / 3 \mathrm{ft}^{2}\left(\text { total area }=4291 \mathrm{~cm}^{2}\right) \text {, } \\
\text { allowed max power output of } 100 \mathrm{~W} .\end{array}$ & 23 \\
\hline $\mathrm{Sn}^{2+} / \mathrm{Sn}^{4+}$ & 6 & $\begin{array}{l}\text { Sn anode mediator }(0.15 \mathrm{~V} \text { vs. NHE }) \text { hydrogenated over } \\
\text { Pt/alumina; } \mathrm{VO}^{2+} / \mathrm{VO}_{2}{ }^{+} \text {cathode mediator }(1 \mathrm{~V} \text { vs. NHE). Max } \\
\text { power density directly reported. }\end{array}$ & 49 \\
\hline $\mathrm{Fe}^{2+} / \mathrm{Fe}^{3+}$ & 6 & $\begin{array}{l}\mathrm{Fe} \text { anode mediator }(0.771 \mathrm{~V} \text { vs. NHE) hydrogenated over } \\
\text { Pt/alumina; } \mathrm{VO}^{2+} / \mathrm{VO}_{2}^{+} \text {cathode mediator }(1 \mathrm{~V} \text { vs. NHE). Max } \\
\text { power density directly reported. }\end{array}$ & 49 \\
\hline $\mathrm{Cu} / \mathrm{Cu}^{2+}$ & 6 & $\begin{array}{l}\mathrm{Cu} \text { anode mediator }(0.337 \mathrm{~V} \text { vs. NHE) hydrogenated over } \\
\mathrm{Pt} / \text { alumina; } \mathrm{VO}^{2+} / \mathrm{VO}_{2}^{+} \text {cathode mediator }(1 \mathrm{~V} \text { vs. NHE). Max } \\
\text { power density is } 124 \mathrm{~mA} \mathrm{~cm} \mathrm{~cm}^{-2} \text { at } 0.72 \mathrm{~V} \text {. }\end{array}$ & 90 \\
\hline $\mathrm{Mo}^{3+} / \mathrm{Mo}^{4+}$ & 7 & $\begin{array}{l}\text { Mo anode mediator ( } \sim 0 \mathrm{~V} \text { vs. NHE) hydrogenated over Pt/silica; } \\
\mathrm{VO}^{2+} / \mathrm{VO}_{2}^{+} \text {cathode mediator }\left(1 \mathrm{~V} \text { vs. NHE) oxidized by } \mathrm{NO}_{\mathrm{x}} \text {. Max }\right. \\
\text { power density is } 81 \mathrm{~mA} \mathrm{~cm} \text { cm }^{-2} \text { at } 0.56 \mathrm{~V} \text {. }\end{array}$ & 45 \\
\hline $\begin{array}{l}\mathrm{SiW}_{12} \mathrm{O}_{40} 5-/ \\
\mathrm{SiW}_{12} \mathrm{O}_{40}^{4-}\end{array}$ & 7 & $\begin{array}{l}\mathrm{H}_{4} \mathrm{SiW}_{12} \mathrm{O}_{40} \text { anode mediator }(\sim 0 \mathrm{~V} \text { vs. NHE) hydrogenated over } \\
\mathrm{Pt} / \text { silica; } \mathrm{VO}^{2+} / \mathrm{VO}_{2}{ }^{+} \text {cathode mediator }(1 \mathrm{~V} \text { vs. NHE) oxidized by } \\
\mathrm{NO}_{\mathrm{x}} \text {. Max power density is } 195 \mathrm{~mA} \mathrm{~cm}{ }^{-2} \text { at } 0.73 \mathrm{~V} \text {. }\end{array}$ & 143 \\
\hline $\begin{array}{c}\mathrm{Fe}(\text { EDTA })^{2-/} \\
\mathrm{Fe}(\text { EDTA })^{-}\end{array}$ & 8 & $\begin{array}{l}\mathrm{Fe}(\mathrm{EDTA}) \text { anode mediator }(0.117 \mathrm{~V} \text { vs. } \mathrm{NHE}) \text { hydrogenated over } \\
\mathrm{Pd} / \text { alumina; } \mathrm{VO}^{2+} / \mathrm{VO}_{2}{ }^{+} \text {cathode mediator }(1 \mathrm{~V} \text { vs. NHE) oxidized } \\
\text { by } \mathrm{NO}_{\mathrm{x}} \text {. Max power density is } 13 \mathrm{~mA} \mathrm{~cm} \mathrm{~cm}^{-2} \text { at } 0.23 \mathrm{~V} \text {. }\end{array}$ & 3 \\
\hline methyl viologen & 9 & $\begin{array}{l}1.5 \mathrm{mM} \text { methyl viologen anode mediator reduced by D. vulgaris; } \\
0.4 \mathrm{mM} \text { ABTS (2,2'-azinobis( } 3 \text {-ethylbenzothiazoline- } 6 \text {-sulfonate) } \\
\text { cathode mediator with } 0.1 \mu \mathrm{m} \text { bilirubin oxidase catalyst for } \mathrm{O}_{2} \\
\text { reduction. } 50 \mathrm{mM} \text { phosphate buffer of pH } 7.0 \text { at atmospheric } \\
\text { pressure at } 25^{\circ} \mathrm{C} \text {. Max current density given as } 0.2 \mathrm{~mA} \mathrm{~cm} \mathrm{~cm}^{-2} \text { at } 0.95 \\
\mathrm{~V} \text { (power density of } 0.19 \mathrm{~mW} \mathrm{~cm}^{-2} \text { ). }\end{array}$ & 0.19 \\
\hline AQS & 9 & $\begin{array}{l}1.5 \mathrm{mM} \text { anthraquinone-2-sulfonic acid anode mediator reduced by } \\
\mathrm{D} \text {. vulgaris; } 1.5 \mathrm{mM} \text { ABTS cathode mediator with } 0.12 \mu \mathrm{m} \\
\text { bilirubin oxidase catalyst for } \mathrm{O}_{2} \text { reduction. Max current density } \\
\text { given as } 0.8 \mathrm{~mA} \mathrm{~cm} \mathrm{~cm}^{-2} \text { at } 0.55 \mathrm{~V} \text { (power density of } 0.44 \mathrm{~mW} \mathrm{~cm} \text { ). }\end{array}$ & 0.44 \\
\hline viologen & 10 & $\begin{array}{l}\text { Viologen moiety immobilized in redox hydrogel with a branched } \\
\text { polyethylenimine backbone and } \mathrm{NiFe} \text { hydrogenase catalyst. } \\
\text { Cathode catalyst is bilirubin oxidase. Max power density given as } \\
0.18 \mathrm{~mW} \mathrm{~cm}^{-2} \text {. }\end{array}$ & 0.18 \\
\hline viologen & 11 & $\begin{array}{l}\text { Viologen moiety immobilized in redox hydrogel with } \mathrm{FeFe} \\
\text { hydrogenase catalyst. Cathode catalyst is bilirubin oxidase. Max } \\
\text { power density given as } 0.23 \mathrm{~mW} \mathrm{~cm}^{-2} \text {. }\end{array}$ & 0.23 \\
\hline
\end{tabular}

The maximum reported power density was calculated from the information given in the reference and is based on the area of the anode. 


\section{References}

(1) Fulmer, G. R.; Miller, A. J. M.; Sherden, N. H.; Gottlieb, H. E.; Nudelman, A.; Stoltz, B. M.; Bercaw, J. E.; Goldberg, K. I. NMR Chemical Shifts of Trace Impurities: Common Laboratory Solvents, Organics, and Gases in Deuterated Solvents Relevant to the Organometallic Chemist. Organometallics, 2010, 29, 2176-2179.

(2) Huskinson, B.; Marshak, M. P.; Suh, C.; Er, S.; Gerhardt, M. R.; Galvin, C. J.; Chen, X.; AspuruGuzik, A.; Gordon, R. G.; Aziz, M. J. A Metal-Free Organic-Inorganic Aqueous Flow Battery. Nature 2014, 505, 195-198.

(3) Carney, T. J.; Collins, S. J.; Moore, J. S.; Brushett, F. R. Concentration-Dependent Dimerization of Anthraquinone Disulfonic Acid and Its Impact on Charge Storage. Chem. Mater. 2017, 29, 4801-4810.

(4) Odyakov, V. F.; Zhizhina, E. G. A Novel Method of the Synthesis of Molybdovanadophosphoric Heteropoly Acid Solutions. React. Kinet. Catal. Lett. 2008, 95, 21-28.

(5) Carson Jr., W. N.; Feldman, M. L. A Redox Type. Proc. Ann. Power Sources Conf. 1959, 13, 111-113.

(6) Oei, D.-G. Chemically Regenerative Redox Fuel Cells. J. Appl. Electrochem. 1982, 12, 41-51.

(7) Kummer, J. T.; Oei, D.-G. A Chemically Regenerative Redox Fuel Cell. II. J. Appl. Electrochem. 1985, 15, 619-629.

(8) Folkesson, B. Chemically Regenerative Redox Fuel Cells II. Regeneration Reaction Studies. $J$. Appl. Electrochem. 1990, 20, 907-911.

(9) Tsujimura, S.; Fujita, M.; Tatsumi, H.; Kano, K.; Ikeda, T. Bioelectrocatalysis-based Dihydrogen/Dioxygen Fuel Cell Operating at Physiological pH. Phys. Chem. Chem. Phys. 2001, 3, 1331-1335

(10) Plumeré, N.; Rüdiger, O.; Oughli, A. A.; Williams, R.; Vivekananthan, J.; Pöller, S.; Schuhmann, W.; Lubitz, W. A Redox Hydrogel Protects Hydrogenase from High-Potential Deactivation and Oxygen Damage. Nat. Chem. 2014, 6, 822-827.

(11) Oughli, A. A.; Conzuelo, F.; Winkler, M.; Happe, T.; Lubitz, W.; Schuhmann, W.; Rüdiger, O.; Plumeré, N. A Redox Hydrogel Protects the O2-sensitive [FeFe]-hydrogenase from Chlamydomonas reinhardtii from Oxidative Damage. Angew. Chem. Int. Ed. 2015, 54, 1232912333. 